\title{
MARGINAL PARODONTOPATHY - A POSSIBLE EFFECT OF CARDIAC PATHOLOGY
}

\author{
Vlad Alin Pantea ${ }^{2,3}$, Larisa Renata Pantea-Roșann ${ }^{1,2}$, Daniela Rahotă², Carmen Radu², \\ Teodor Maghiar ${ }^{2}$ \\ ${ }^{1}$ Clinical County Emergency Hospital of Oradea, Bihor \\ ${ }^{2}$ Faculty of Medicine and Pharmacy, University of Oradea \\ ${ }^{3}$ Dental office - CMI Dr. Pantea Vlad Alin \\ Corresponding author: Iarisa.rosan@yahoo.com
}

\section{Rezumat}

Parodontopatia marginală cronică este dată de afectarea mucoasei gingivale și a structurilor profunde ale parodonțiului, cauzată de un process inflamator cronic. În continuare vom prezenta un pacient în vârstă de 46 de ani, fără antecedente cardiovasculare cunosute, ce se prezintă la medicul dentist în vederea soluționării paroprotetice a arcadei superioare, la care se va decela prezența fibrilației atriale și a trombembolismului pulmonar.

Cuvinte cheie: parodontopatia marginală, fibrilația atrială, trombembolismul pulmonar

\section{Abstract}

Chronic marginal periodontal disease is caused by the damage to the mucous membrane of the gum and the profound structures of the periodontium caused by a chronic inflammatory process. Next, we will present a 46-year-old patient with no known cardiovascular antecedents, presenting to the dentist for the paroprotective solution of the upper arcade, at which the presence of atrial fibrillation and pulmonary thromboembolism.

Keywords: marginal parodontopathy, atrial fibrillation, pulmonary thromboembolism 


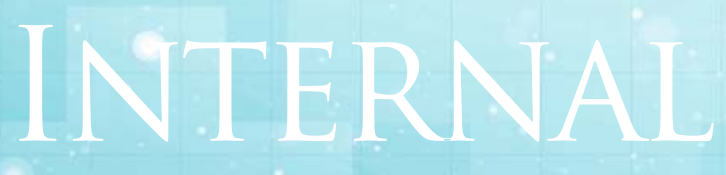

Clinical cases

A 46-year-old patient known as fixed total maxillary prosthetic work is present in the dental office for ablation because three of the four supporting teeth of the paper show the degree of mobility 3 causing gingival injuries incompatible with the exercise of the function of the device dento-maxillary, at the same time anamnestic we note that it also has inspiratory dyspnoea of about 5 days.

From our heredo-collateral history, we note that his mother has hypertension. As behaviors we remember that the patient is a smoker, does not consume toxic and does not follow a background medication.

In the objective examination we observe a good general condition, normally colored stains, RF 24 breaths / min, HR 135 b / min, BP $145 / 90 \mathrm{mmHg}, \mathrm{SaO} 288 \%$ without O2, and in the oral cavity we notice erythematous lesions, poor hygiene, dental plaque in the mandibular arches and the mobility of the fixed work, being supported only by the molar 2 on the hemiarcada 1 (Figure 1 ).

Taking into account the anamnestic data correlated with the general objective examination carried out in the dental office, it is decided to guide the patient to the emergency departament.

In the emergency departament, an electrocardiogram is performed which detects atrial fibrillation, HR 144 b / min, QRS +60 axis (Figure 2). The echocardiography performed at the admission in the emergency departament outlines LV within normal limits, LV ejection fraction $\sim 40 \%$, LA of elevated diameters, dilated RV (Figure 3 ). The laboratory tests show mild microchip anemia, hypochroma (HGB 10,122 g/ dl, MCV $76,52 \mathrm{fl}, \mathrm{MCHC} 30,41 \mathrm{~g} / \mathrm{dl}$ ), D-dimer shows elevated values ( $>5 \mu \mathrm{g} / \mathrm{ml}$ ), resting normal values NTproBNP (1834 pg / ml).

Angio-CT pulmonary arteries are performed showing signs of pulmonary thromboembolism in the lower lobar arteries and bilateral segmentation (Figure 4 ).

Based on the anamnestic data correlated with the objective examination and the paraclinical evaluations, the diagnosis of: pulmonary thromboembolism, atrial fibrillation diagnosed first with high ventricular alloria, microchip anemia hypochroma, rapid progressive chronic periodontitis, dental plaque.

The patient is advised to initiate treatment with new oral anticoagulants, beta-blockers, diuretics, iron-based preparations, to delay the ablation of the fixed work and dental extractions required by the dentist in collaboration with the cardiologist.

\section{DISCUSSION}

Marginal periodontitis involves damage to the alveolar bone which is made either by demineralization or by destruction, the periodontal ligament being affected by the 


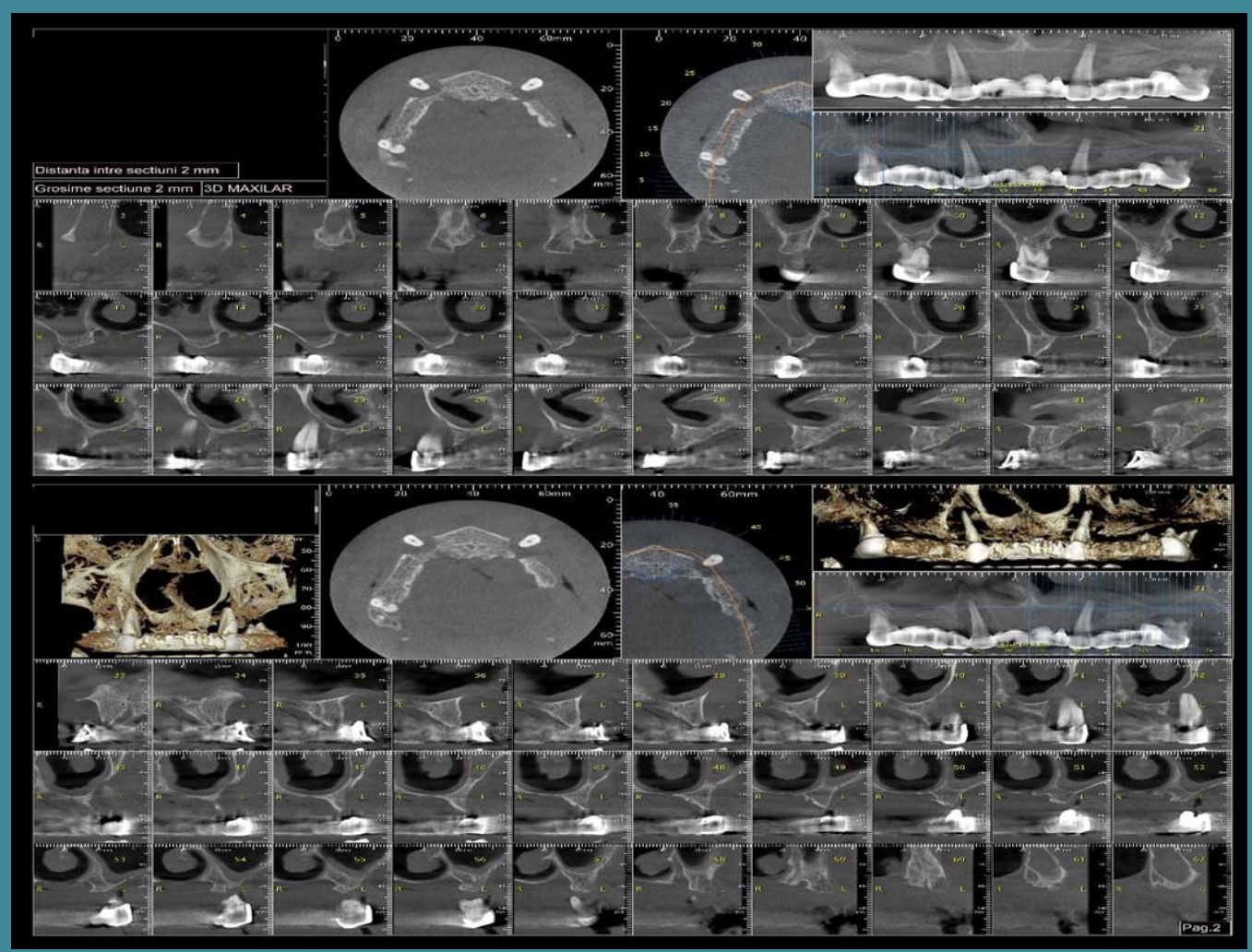

Figure 1. 3D CBCT maxilar image

(1)

Figure 2. The electrocardiogram 


\section{INTE}

inflammatory factor ${ }^{(1)}$. Atrial fibrillation is a cardiac arrhythmia at high risk of embolization at the cerebral level, and cases of thrombus thrombosis in the right cavity with pulmonary thromboembolism ${ }^{(2)}$. Pulmonary thromboembolism is considered an emergency cardiovascular diagnosis by the malignant potential of cardiogenic shock and cardio-pulmonary arrest ${ }^{(3)}$.

Data from the literature show that association of atrial fibrillation with pulmonary thromboembolism significantly increases the risk of in-hospital death compared to patients who do not have this association $^{(4)}$, while treatment with new oral anticoagulants has been shown to help reduce hospital days and the risk of hospital death by increasing the efficacy and safety of treatment ${ }^{(5)}$.

\section{References}

1. Horia Traian Dumitriu, Silvia Dumitriu, Anca Silvia Dumitriu. Parodontologie, Editia A V-a, Ed. Viata Medicala Romaneasca, Bucuresti 2009

2. Carmen Ginghina. Mic tratat de cardiologie, Editia a II-a, Ed. Academiei Române, București 2017

3. Eduard Apetrei. Cardiologieclinică, Ed. Medicală Callisto, București 2015

4. Keller K, Hobohm L, Munzel Th, Ostad MA. Syncope in the German Nationwide inpatient sample - Syncope in atrial fibrillation/flutter is related to pulmonary embolism and is accompanied by higher inhospital mortality. European Journal of Internal Medicine 2019, https://doi.org/10.1016/j.ejim.2019.02.005

5. Otilia Anca Tica, Ovidiu Țica, Liana Antal, Adrian Hatos, Mircea loachim Popescu, Anca Pantea Stoian, Ovidiu Gabriel Bratu, Mihnea-Alexandru Găman, Silviu Mirel Pițuru, Camelia Cristina Diaconu. Modern oral anticoagulant treatment in patients with atrial fibrillation and heart failure: insights from the clinical practice. Farmacia 2018 66(6): 972-976, DOI: 10.31925/FARMACIA.2018.6.7 


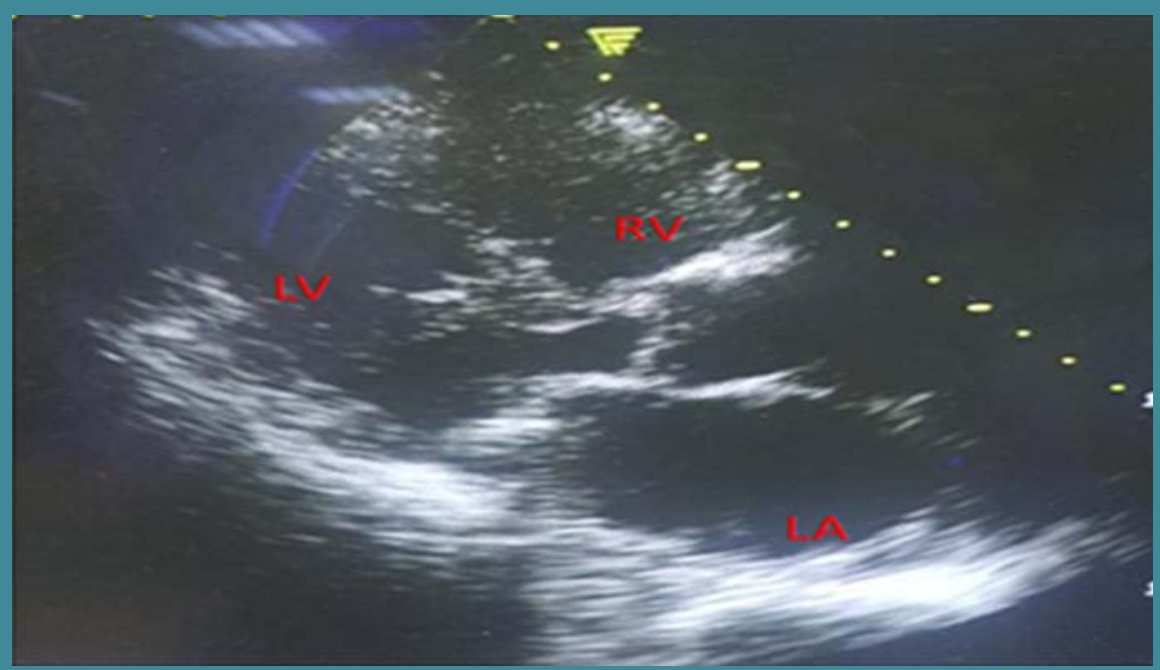
LA - Left Atrium
LV - Left Ventricle
RV - Right Ventricle

Figure 3. The echocardiography: parasternal long axis view

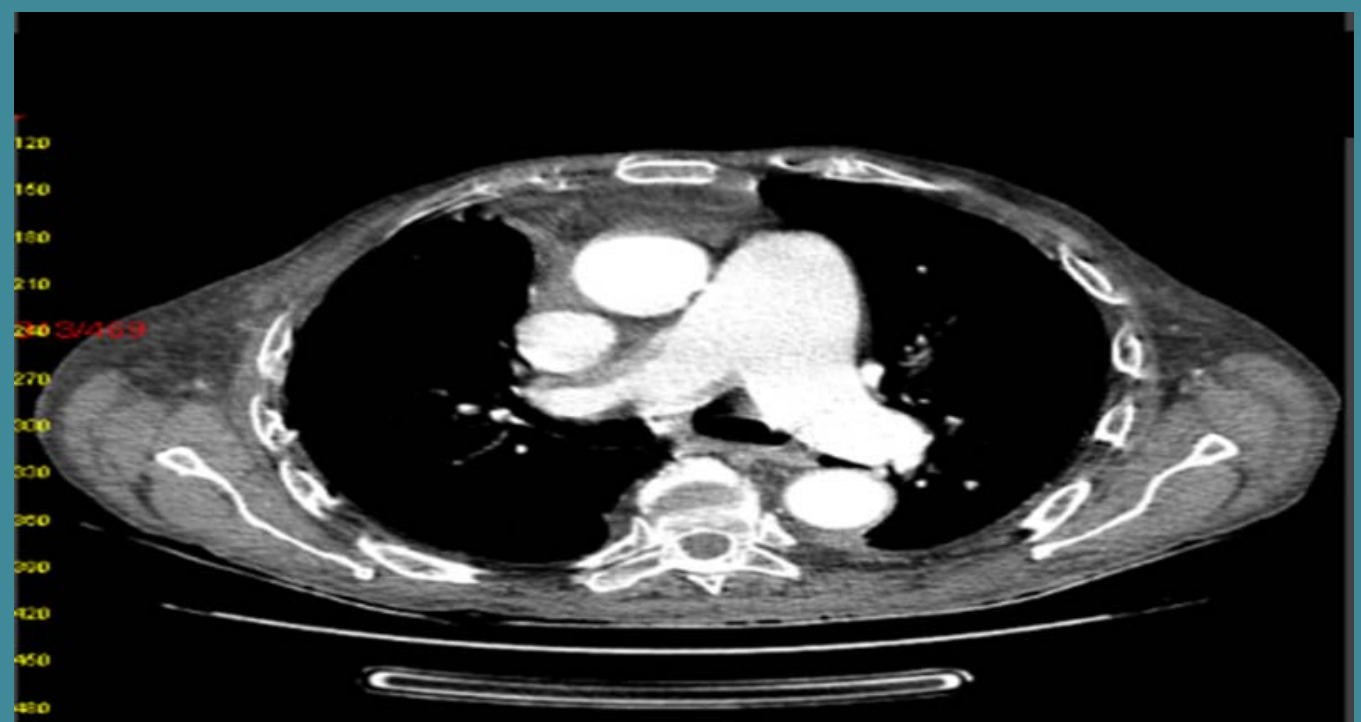

Figure 4. Angio-Ct pulmonary arteries 